\title{
RESPIRATORY ACTIVITY FOR THE DIFFERENTIATION OF VIGOR ON SOYBEAN SEEDS LOTS ${ }^{1}$
}

\author{
CRISTINA RODRIGUES MENDES², DARIO MUNT DE MORAES ${ }^{3}$, \\ MARIA DA GRAÇA DE SOUZA LIMA4 ${ }^{4}$, NEI FERNANDES LOPES ${ }^{5}$
}

\begin{abstract}
Currently, the highest interest with respect to the assessment of seed physiological quality is to obtain reliable results in a relatively short period of time. This initiative allows for prompt decisions during different phases of seed production primarily after physiological maturity. This research was performed to verify the efficiency and rapidity of the method of Pettenkofer to determine the respiratory activity and to differentiate vigor levels of soybean seed lots. Three lots of soybean seeds cv. 8000 were used. Seed performance was determined by respiratory activity, compared to the following tests: standard germination, germination first count, electrical conductivity, seedling emergence, seedling shoot and root length and total dry mass. Results ranked seed lots according to defferences in physiological quality. Seed imbibition and conditioning period in Pettenkofer's equipment were enough to detect differences in vigor among seed lots, showing that the determination of the respiratory activity is a promising procedure to identify differences in vigor levels among soybean seed lots.
\end{abstract}

Index terms: physiological quality, respiration, seed analysis.

\section{ATIVIDADE RESPIRATÓRIA PARA A DIFERENCIAÇÃO DO VIGOR DE LOTES DE SEMENTES DE SOJA}

\begin{abstract}
RESUMO - Um dos aspectos mais importantes da avaliação da qualidade fisiológica das sementes é a obtenção de resultados confiáveis em período de tempo relativamente curto. Essa rapidez permite a pronta tomada de decisões durante diferentes etapas da produção de sementes. Portanto, este trabalho teve por objetivo avaliar a eficiência e rapidez do método de Pettenkofer na determinação da atividade respiratória para diferenciar o vigor de lotes de sementes de soja. Para tanto, foram utilizados lotes de sementes de soja cv. 8000. Além da determinação da atividade respiratória, foram conduzidos os seguintes testes, considerados eficientes para identificar o potencial de desempenho das sementes: grau de umidade, germinação, primeira contagem da germinação, condutividade elétrica, emergência de plântulas, comprimento de parte aérea, raiz e massa seca total. Os resultados desses testes e a determinação da atividade respiratória das sementes permitiram a classificação dos lotes em diferentes níveis de qualidade fisiológica. O período de embebição e de permanência das sementes no aparelho de Pettenkofer foi suficiente para proporcionar a distinção dos lotes, de modo que a determinação da atividade respiratória constitui procedimento promissor para identificar diferenças na qualidade fisiológica de sementes de soja.
\end{abstract}

Palavras chave: análise de sementes, qualidade fisiológica, respiração.

\footnotetext{
${ }^{1}$ Submetido em 28/08/2008. Aceito para publicação em 18/12/2008. parte da Tese de Doutorado em Fisiologia Vegetal pelo primeiro autor.

$2 / 4$ Eng. Agr., Dr. Depto de Botânica, Instituto de Biologia, CP 354, Universidade Federal de Pelotas, CEP 96010-900, Pelotas, RS. e-mail:
}

cmendess@bol.com.br.; magali@ufpel.tche.br

${ }^{3 / 5}$ Prof. Dr. do Depto de Botânica, Instituto de Biologia, CP 354, UFPel, CEP96010-900,Pelotas, RS.e-mail:moraesdm@ufpel.tche.br; neiflopes@ ufpel.tche.br 


\section{INTRODUCTION}

The quality of a seed lot contains a series of attributes that determine their value for seeding, involving components of a genetic, physical, physiological and health (Popinigis, 1985). The four basic attributes of quality seeds have similar importance, but the physiological generally arouses attention of the research, to further elucidate the various aspects relating to the viability and seed vigor (Marcos Filho, 2005).

Although routine, the germination test does not provide information on the potential for seedling emergence in field events and the physiological and degree of deterioration and the storage potential. Moreover, it needs a relatively long time to obtain results, considered excessive to meet the commercial interests of producers of seeds. In this situation, the modern agriculture recommends the composition of quality control programs, including additional testing, reliable, reproducible and rapid. Rapid quality assessment of seed allows making decisions early, during different stages of seed production, especially between the ripening stage and the future sowing (Dias and Marcos Filho, 1996).

The tests for the rapid assessment of viability or vigor represent important components of the programs of quality control of seeds, allowing more flexible to obtain information through the disposal of lots of lower quality during the reception at the processing and rationalization of management, with the most efficient use of available infrastructure (Marcos Filho, 2005).

The tetrazolium test is considered rapid and sensitive for evaluating the physiological quality of seeds, estimating the viability based on color change of the living tissues of the embryo in the presence of tetrazolium chloride solution, reflecting the activity of enzymes involved in the dehydrogenases process of respiration of seeds, these enzymes catalyze the reaction of reduction of the tetrazolium salt in living cells. Shall be construed as limitations of the test does not really allow for the detection of the presence of dormant seeds of damage caused by chemicals, and require expertise (seed structure and vital areas), training of analysts and number of hours human compared to the germination test (Peske et al., 2006).

The first metabolic activity, identified at the beginning of the rehydration of the seed, is the increase of respiration which, in minute amounts, reaches high levels, shortly after the start of imbibition (Ferreira and Borghetti, 2004). The integrity and activity of mitochondria of viable embryos amounted to from the start of imbibition, making for more efficient production of ATP, reflecting the increase in oxygen consumption (Bewley and Black, 1994). The activity of enzymes and organelles, respiration and synthesis of proteins are key events for the normal development of the process of preparation for germination and subsequent growth of the embryo (Marenco and Lopes, 2007).

The increased respiration of the seed can be measured by the amount of carbon dioxide $\left(\mathrm{CO}_{2}\right)$ released by the amount of oxygen $\left(\mathrm{O}_{2}\right)$ consumed or released by the relationship between $\mathrm{CO}_{2}$ and $\mathrm{O}_{2}$ consumption $\left(\mathrm{CO}_{2} / \mathrm{O}_{2}\right)$ called respiratory quotient (Popinigis, 1985).

Respiration involves the loss of dry matter and gas exchange, parameters used to determine this physiological process, however the determination of the variation of dry mass requires large amounts of material and usually involves their destruction. The methods based on gas exchange are more sensitive, requires smaller amounts of material and are not destructive and can be the determination of $\mathrm{O}_{2}$ consumption gauge or the $\mathrm{CO}_{2}$ released by using physical methods such as infrared gas analyzer. There are also physical-chemical procedures based on the retention of $\mathrm{CO}_{2}$ in a base and its determination by titrimetric, colorimetric or conductivimeter (Maestri et al., 1998).

The respiratory metabolism related with germination, mineral leaching, storage, and deterioration of soybean seeds (Satterlee and Koller, 1984; Kishitani and Shibles, 1986, Ferguson et al., 1990), maize (Cantrell et al., 1972) and cotton (Woodstock et al., 1985). Soybean seed harvested before physiological maturity have lower rate of respiration in the initial phase of the process of germination (Miles et al., 1988). Since immature seeds generally have less vigor, it can be inferred that this experiment provided an indication of a relationship between vigor and rate of respiration of seeds.

Thus, this work aimed to verify whether the assessment of respiratory activity of seeds by the method physicochemical of Pettenkofer, may be related to results of other tests recommended for the determination of the physiological quality of soybean seeds and also to evaluate the efficiency of the method to distinguish the vigor of lots in relatively short period, to provide a simple and objective option for use in laboratories for the analysis of seeds.

\section{MATERIAL AND METHODS}

The research was developed in the seeds laboratory and in the greenhouse of the Department of Botany, Federal University of Pelotas (UFPel). For this were used three lots of soybean seeds, cultivar 8000 , provided by the Department of Crop, Agronomy Faculty Eliseu Maciel, UFPel. 
Seed performance was determined by respiratory activity, compared to the following tests: standard germination, germination first count, electrical conductivity, seedling emergence, seedling shoot and root length and total dry mass.

Moisture content (MC) was determined by the method of oven at $105 \pm 3{ }^{\circ} \mathrm{C}$ for 24 hours, according to the Rules for Seed Analysis - RAS (Brasil, 1992). This determination was conducted with two replicates of approximately five grams of seeds for each lot, and the results expressed as average percentage on wet basis. Germination (G) was performed with three replicates of 200 (four replicates of 50) seeds per lot. The seeds were distributed on paper germitest, moistened with water amount equivalent to 2.5 times the mass of dry substrate and maintained in germination chamber at $25^{\circ} \mathrm{C}$. The final count of germination was determined on the eighth day after being sowed as RAS (Brasil, 1992), and the results expressed as average percentage of normal seedlings for each lot. Germination first count (GFC) the record consisted of the percentage of normal seedlings on the fifth day after the installation of the germination test described in the previous item. Electrical conductivity (EC) was performed with three replicates of 100 seeds physically pure (four replicates of 25). In order to measured the mass, the seeds were placed to soak in becker container with $80 \mathrm{~mL}$ of deionized water, shaken gently, so that all were completely submerged, and kept in germination chamber at $20^{\circ} \mathrm{C}$ for three or 24 hours. Then made to read the EC of water imbibition in conductivimeter Digimed model CD-21, the results were expressed in $\mu \mathrm{S} \mathrm{cm}^{-1}$ $\mathrm{g}^{-1}$ for each lot of seed (AOSA, 2002). Seedling emergence (E) the seedling was done in polystyrene trays with 128 cells of $60 \mathrm{~mm}$ in depth, under greenhouse conditions in washed sand, with three replicates of 200 seeds ( four subsamples of 50 ) were held daily irrigation as needed. The results were expressed as mean percentage of seedlings emerged, at 21 days after installation of the experiment. Seedling shoot (SL) and root (RL) length and total dry mass (TDM) the collection comprised of 10 seedlings of each subsample obtained on the 21 days of installation of the seedling emergence. The values of SL and RL were divided by the number of seedlings evaluated and the results expressed in $\mathrm{mm}$ seedling ${ }^{-1}$, after they were placed in forced ventilation oven at $70 \pm 2^{\circ} \mathrm{C}$ until constant weight, checking the same gravimetrically and the results expressed in $\mathrm{mg} \mathrm{seedling}^{-1}$ for each lot.

Respiratory activity (RA) - the release of $\mathrm{CO}_{2}$ by the seeds was determined by the Pettenkofer apparatus consists of four bottles of gas scrubbers, two of which contained sodium hydroxide $(\mathrm{NaOH})$ to $25 \%$, which is to retain the $\mathrm{CO}_{2}$ of ambient air, in one of the bottles was used to storage of seeds, free of $\mathrm{CO}_{2}$ from ambient air and the other containing barium hydroxide $\mathrm{Ba}(\mathrm{OH})_{2}$ to $25 \%$, which reacts with the $\mathrm{CO}_{2}$ from the respiratory activity of seeds, resulting in barium carbonate $\left(\mathrm{BaCO}_{3}\right)$. The bottles were connected by a hose silicone tube attached to a suction of air. The seeds of the three lots $(200 \mathrm{~g})$ were placed in distilled water to soak the bottle in storage for 60 minutes at $25^{\circ} \mathrm{C}$ in a water bath. After the soaking period was removed and the excess water bottle that was connected to the other and the unit was activated for 60 minutes at $25^{\circ} \mathrm{C}$. After the period of permanence of seeds in the unit were collected five aliquots of $10 \mathrm{~mL}$ solution of $\mathrm{BaCO}_{3}$ in an Erlenmeyer flask where each, after receiving two drops of phenolphthalein color reagent, was subjected to titration with hydrochloric acid $(\mathrm{HCl}) 0.1 \mathrm{~N}$ in the $50 \mathrm{~mL}$ burette. In the turning point, detected by changing the color of the solution pink to white, was recorded the volume of $\mathrm{HCl}$ spent in each aliquot. This volume, directly related to the intensity of $\mathrm{CO}_{2}$ fixed by the solution of $\mathrm{Ba}(\mathrm{OH})_{2}$, is used to calculate the respiratory activity of seeds, and set the $\mathrm{CO}_{2}$ from the process of respiration. The calculation of the respiratory activity was performed using the following equation: N x D x 22 (Müller, 1964), where $\mathrm{N}=$ normality of acid used $(\mathrm{HCl} 0.1 \mathrm{~N}), \mathrm{D}=$ difference between the volume of spent $\mathrm{HCl}$ titration proof of blank and the volume of spent $\mathrm{HCl}$ titration sample, 22 = normality of $\mathrm{CO}_{2}$. The result was expressed as the quantity of carbon dioxide released per gram of seed and per hour $\left(\mu \mathrm{g} \mathrm{CO}_{2} \mathrm{~g}^{-1}\right.$ seed $\left.\mathrm{h}^{-1}\right)$.

It was used a completely randomized design with five replicates for the determination of respiratory activity and three for the other tests, and the averages compared by Tukey test $(\mathrm{p} \leq 0.05)$.

\section{RESULTS AND DISCUSSION}

The moisture content of three lots of soybean cultivar 8000 was similar, ranging from $12.1 \%$ to $12.5 \%$. Lots 01 and 02 showed higher standard germination than the lot 3 , which did not meet the minimum germination for the marketing of soybean seeds, similar behavior was observed on germination first count (Table 1). It is important that these tests were performed only to compare their results with those obtained in the determination of respiratory activity of seeds after 60 minutes of soaking and 60 minutes to stay in apparatus of Pettenkofer.

The electrical conductivity test in two periods of imbibition indicated the lot 02 and lot 03 as that solutes 
leached more, becoming as medium and low quality physiological respectively (Table 1). Moreover, the lot 01 had lower rate of leaching of solutes, revealing to be the lot of more vigor. Thus, the electrical conductivity test, with reading after 24 hours of soaking, had sufficient sensitivity to differentiate the physiological quality of the lots here evaluated.

TABLE 1. Moisture content (MC), germination (G), germination first count (GFC) and electrical conductivity (EC), three and 24 hours of soaking in three seed lots of soybean cv. 8000

\begin{tabular}{llllll}
\hline Lot & MC (\%) & G (\%) & GFC $(\%)$ & \multicolumn{2}{l}{$\mathrm{EC}\left(\mu \mathrm{S} \mathrm{cm}^{-1} \mathrm{~g}^{-1}\right.$} \\
\cline { 5 - 6 } & & & & $3 \mathrm{hs}$ & $24 \mathrm{hs}$ \\
\hline 01 & 12,1 & $85,7 \mathrm{~A} *$ & $79,0 \mathrm{~A}$ & $15,13 \mathrm{~B}$ & $35,24 \mathrm{C}$ \\
02 & 12,2 & $80,3 \mathrm{~A}$ & $79,3 \mathrm{~A}$ & $15,35 \mathrm{~B}$ & $38,49 \mathrm{~B}$ \\
03 & 12,5 & $49,0 \mathrm{~B}$ & $44,0 \mathrm{~B}$ & $18,84 \mathrm{~A}$ & $58,68 \mathrm{~A}$ \\
\hline $\mathrm{CV}(\%)$ & - & 5,85 & 3,76 & 5,42 & 3,40 \\
\hline
\end{tabular}

* Averages followed by same letter in column do not differ by Tukey test at $5 \%$ probability.

The determination of electrical conductivity of the solution of imbibition of the seed, as a test of vigor, is recommended for pea seeds and suggested for soybean (AOSA, 2002), a species that has been observed relationship between the test results of electrical conductivity with seedling emergence (Vieira et al., 1999a and b). According to Powell (1986) as the seed is developed for physiological maturity, showing the structural organization of cell membranes, which explains the high electrical conductivity when the seeds are not yet fully formed. Tests based on the integrity of membranes of the seed are deserving special attention, for identifying the deterioration process in its early stages and allow corrective measures are taken to reduce or minimize its effect on physiological quality of seed. Among the methods that are based on this principle there are tests of electrical conductivity, leaching of potassium and $\mathrm{pH}$ of the exudate (Peske et al, 2006).

The results for seedling emergence under greenhouse conditions, shoot and root length and total dry mass (Table 2) were comparable to the electrical conductivity test after 24 hours (Table 1) to characterize the lots 01 and 02 as to vigor higher, agreeing with Miguel and Cicero (1999), using soybean seeds verified a positive correlation between test results of emergence and electrical conductivity on the field after 24 hours, and Dan et al. (1987) also that seeds of high vigor produce seedlings with greater growth rate due to better capacity for metabolism of reserves.

TABELA 2. Seedling emergency (E), shoot (SL) and root (RL) length and total dry mass (TDM) of seedlings from three seed lots of soybean $\mathrm{cv}$. 8000

\begin{tabular}{|c|c|c|c|c|}
\hline \multirow{2}{*}{ Lot } & \multirow{2}{*}{$\mathrm{E}(\%)$} & SL & RL & \multirow{2}{*}{$\begin{array}{l}\text { TDM } \\
\left(\mathrm{mg} \mathrm{seedling}^{-1}\right)\end{array}$} \\
\hline & & \multicolumn{2}{|c|}{$\left(\mathrm{mm}\right.$ seedling $\left.{ }^{-1}\right)$} & \\
\hline 01 & $87,0 \mathrm{~A}^{*}$ & $195,0 \mathrm{~A}$ & $334,5 \mathrm{~A}$ & $352,1 \mathrm{~A}$ \\
\hline 02 & $82,3 \mathrm{~B}$ & 158,1 & $298,0 \mathrm{~B}$ & $317,0 \mathrm{~B}$ \\
\hline 03 & $31,3 \mathrm{C}$ & 112,7 & $268,2 \mathrm{C}$ & $284,9 \mathrm{C}$ \\
\hline $\mathrm{CV}(\%)$ & 2,05 & 3,69 & 1,12 & 3,86 \\
\hline
\end{tabular}

* Averages followed by same letter in column do not differ by Tukey test at $5 \%$ probability.

The respiratory activity, obtained by the method of Pettenkofer, the three seed lots of soybean cv. 8000 is shown in Figure 1. Lots 01, 02 and 03 showed high, medium and low respiratory activity, respectively. These results showed the same trend as the majority of tests conducted in this study (Tables 1 and 2) to separate lots at different levels of vigor.

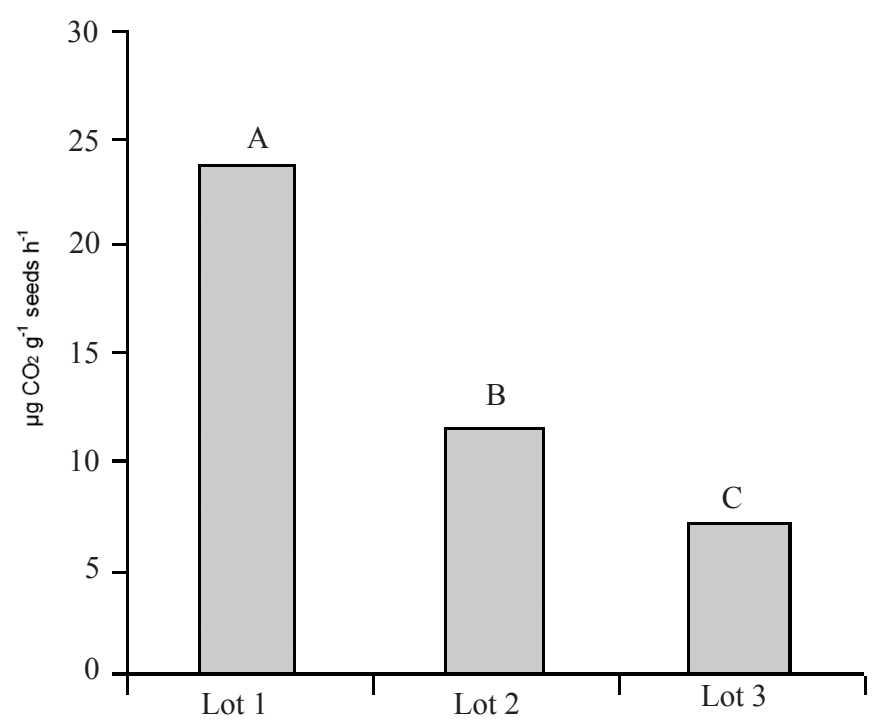

FIGURE 1. Average of respiratory activity of three seed lots of soybean cultivar 8000 , determined by the amount of $\mathrm{CO}_{2}$ released. 
Polls indicate that mitochondria in dry seeds and the beginning of the process of soaking, have no organized system of membranes, the structural recovery occurs as the hydration proceeds, so the mitochondria become more efficient in oxidative phosphorylation. The maintenance of vigor can be viewed as a consequence the time required for the mitochondrial respiratory functions will run normal, and the system of membranes, better organized (Marcos Filho, 2005). The activity and integrity of the mitochondria of viable embryos increased from the start of imbibition, which makes for more efficient production of ATP, reflecting the elevated oxygen consumption (Bewley and Black, 1994).

The periods of seed imbibition (60 minutes) and stay in the apparatus of Pettenkofer (60 minutes) were sufficient to permit the separation of the lots on the physiological quality (Figure 1). So, despite having been held in three lots, the determination of respiratory activity of seeds at the initial stage of germination should be object of future studies as a possible method for the rapid assessment of the quality of seeds, with the advantages to the relatively short period delivering results and low cost the equipment used.

\section{CONCLUSION}

The determination of respiratory activity of seeds has potential for use as a method to evaluate the physiological quality of soybean seeds.

\section{REFERENCES}

ASSOCIATION OF OFFICIAL SEED ANALYSTS (AOSA). Seed Vigor Testing Handbook. Lincoln. 2002. 105p. (Contribution 32).

BEWLEY, J.D.; BLACK, M. Seeds: physiology of development and germination. 2.ed. New York, Plenum Press, 1994. 445p.

BRASIL. Ministério da Agricultura e Reforma Agrária. Regras para Análise de Sementes. Brasília: SNAD/CLAV, 1992. 365p.

CANTRELL, R.P.; HODGES, H.F.; KEIM, W.F. Relationship Between Plant Respiration and Seedling Vigor in Zea mays L. Crop Science, v.12, p.214-216, 1972.

DAN, E. L.; MELLO, V. D. C.; WETZEL, C. T. Transferência de matéria seca como método de avaliação do vigor de sementes de soja. Revista Brasileira de Sementes, v.9, n.3, p.45-55, 1987.

DIAS, D.C.F.S.; MARCOS FILHO, J. Testes de condutividade elétrica para avaliação do vigor de sementes de soja (glycine max (1.) merrill). Scientia Agricola, v.53, n.1, p 31-42, 1996.

FERGUSON, J.M.; TEKRONY, D.M.; EGLI, D.B. Changes During Early Seed and Axes Deterioration: I. Seed Quality and Mitochondrial Respiration Crop Science, v.30, p.175179, 1990.

FERREIRA, A.G.; BORGHETTI, F. Germinação: do básico ao aplicado. Porto Alegre: Artmed, 2004. 323p.

KISHITANI, S.; SHIBLES, R. Respiration rates of soybean cultivars. Crop Science, v.26, p.580-583, 1986.

MAESTRI, M.; ALVIM, P. de T; SILVA, M.A.P. Fisiologia Vegetal; exercícios práticos. Viçosa: UFV, 1998. 91p. (Cadernos didáticos, 20).

MARCOS FILHO, J. Fisiologia de Sementes de Plantas Cultivadas. Piracicaba: Fealq, 2005. 495p.

MARENCO, R.A.; LOPES, N.F. Fisiologia Vegetal: fotossíntese, respiração, relações hídricas e nutrição mineral. 2. ed. Viçosa: UFV, 2007. 469p.

MIGUEL, M.L.; CÍCERO, S.M. Teste de frio na avaliação do vigor de sementes de soja. Revista Brasileira de Sementes, v.21, n.2, p.35-42, 1999.

MILES, D.F.; TEKRONY, D.M.; EGLI, D.B. Changes in Viability, Germination, and Respiration of Freshly Harvested Soybean Seed During Development. Crop Science, v.28 p:700-704, 1988.

MÜLLER, L.E. Manual de Laboratório de Fisiologia Vegetal. Instituto Interamericano de Ciencias Agricolas de la O.E.A.. Turrialba, Costa Rica, 1964. 165p.

PESKE, S.T.; LUCCA FILHO, O.A.; BARROS, A.C.S.A. Sementes: fundamentos científicos e tecnológicos. 2.ed. Pelotas: Ed. Universitária/UFPel, 2006. 470p.

POPINIGIS, F. Fisiologia da Semente. 2.ed. Brasília, Agiplan, 1985. 289p.

POWELL, A.A. Cell membranes and seed leachate condutivity in relation to the quality of seed for sowing. Journal of Seed Technology, v.10, n.2, p. 81-100, 1986.

SATTERLEE, L.D.; KOLLER, H.R. Response of soybean fruit respiration to changes in whole plant light and $\mathrm{CO}_{2}$ environment. Crop Science, v.24, p.1007-1010, 1984.

VIEIRA, R.D.; PAIVA-AGUERO, J.A.; PERECIN, D. Eletrical conductivity and field performance of soybean seeds. Seed Technology, v.21, n.1, p.15-24, 1999a.

VIEIRA, R.D.; PAIVA-AGUERO, J.A.; PERECIN, 
D.; BITTENCOURT, S.R.M. Correlation of electrical conductivity and other vigor tests with field emergence of soybean seedlings. Seed Science and Technology, v.27, n.1, p.67-75, 1999b.
WOODSTOCK, L.W.; FURMAN, K.; LEFFLER, H.R. Relationship between weathering deterioration and germination, respiratory metabolism and mineral leaching from cottonseeds. Crop Science, v.25, p.459-466, 1985. 